\title{
Front Matter: Volume 11365
}

, "Front Matter: Volume 11365," Proc. SPIE 11365, Organic Electronics and Photonics: Fundamentals and Devices II, 1136501 (24 April 2020); doi:

$10.1117 / 12.2571773$

SPIE. Event: SPIE Photonics Europe, 2020, Online Only 


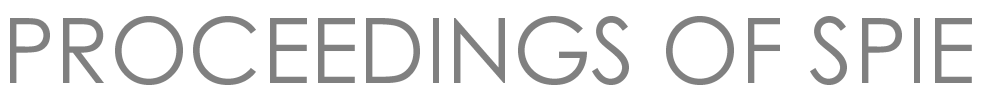

\title{
Organic Electronics and Photonics: Fundamentals and Devices II
}

\author{
Sebastian Reineke \\ Koen Vandewal \\ Wouter Maes \\ Editors \\ 6-10 April 2020 \\ Online Only, France \\ Sponsored by \\ SPIE \\ Cosponsored by \\ City of Strasbourg (France) \\ Eurometropole (France) \\ CNRS (France) \\ iCube (France) \\ Université de Strasbourg (France) \\ Cooperating Organisations \\ Photonics 21 (Germany) \\ EOS-European Optical Society (Germany) \\ Photonics Public Private Partnership (Belgium) \\ Photonics France (France) \\ Published by \\ SPIE
}

Volume 11365 
The papers in this volume were part of the technical conference cited on the cover and title page. Papers were selected and subject to review by the editors and conference program committee. Some conference presentations may not be available for publication. Additional papers and presentation recordings may be available online in the SPIE Digital Library at SPIEDigitalLibrary.org.

The papers reflect the work and thoughts of the authors and are published herein as submitted. The publisher is not responsible for the validity of the information or for any outcomes resulting from reliance thereon.

Please use the following format to cite material from these proceedings:

Author(s), "Title of Paper," in Organic Electronics and Photonics: Fundamentals and Devices II, edited by Sebastian Reineke, Koen Vandewal, Wouter Maes, Proceedings of SPIE Vol. 11365 (SPIE, Bellingham, WA, 2020) Seven-digit Article CID Number.

ISSN: 0277-786X

ISSN: 1996-756X (electronic)

ISBN: 9781510635029

ISBN: 9781510635036 (electronic)

Published by

SPIE

P.O. Box 10, Bellingham, Washington 98227-0010 USA

Telephone +1 3606763290 (Pacific Time) · Fax +1 3606471445

SPIE.org

Copyright @ 2020, Society of Photo-Optical Instrumentation Engineers.

Copying of material in this book for internal or personal use, or for the internal or personal use of specific clients, beyond the fair use provisions granted by the U.S. Copyright Law is authorized by SPIE subject to payment of copying fees. The Transactional Reporting Service base fee for this volume is $\$ 18.00$ per article (or portion thereof), which should be paid directly to the Copyright Clearance Center (CCC), 222 Rosewood Drive, Danvers, MA 01923. Payment may also be made electronically through CCC Online at copyright.com. Other copying for republication, resale, advertising or promotion, or any form of systematic or multiple reproduction of any material in this book is prohibited except with permission in writing from the publisher. The CCC fee code is $0277-$ $786 \times / 20 / \$ 18.00$.

Printed in the United States of America.

Publication of record for individual papers is online in the SPIE Digital Library.

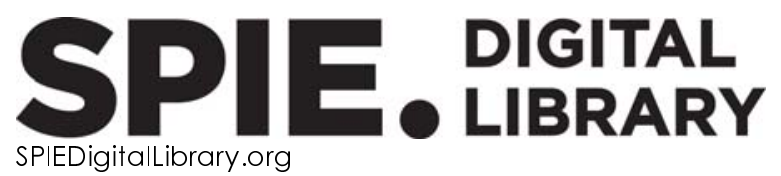

Paper Numbering: Proceedings of SPIE follow an e-First publication model. A unique citation identifier (CID) number is assigned to each article at the time of publication. Utilization of CIDs allows articles to be fully citable as soon as they are published online, and connects the same identifier to all online and print versions of the publication. SPIE uses a seven-digit CID article numbering system structured as follows:

- The first five digits correspond to the SPIE volume number.

- The last two digits indicate publication order within the volume using a Base 36 numbering system employing both numerals and letters. These two-number sets start with 00, 01, 02, 03, 04, 05, 06, 07, 08, 09, OA, OB ... 0Z, followed by 10-1Z, 20-2Z, etc. The CID Number appears on each page of the manuscript. 


\section{Contents}

$\begin{array}{cl}\vee & \text { Authors } \\ \text { vii } & \text { Conference Committee }\end{array}$

ORGANIC ELECTRONIC DEVICES AND OLEDS I

1136505 Inkjet printing of multiple layers for large-scale, cadmium-free quantum dot light-emitting diodes [11365-4]

\section{POSTER SESSION}

1136500 Innovation management in laser research: research project combines technological development with economic benefits (final main results) [11365-24]

$113650 Q$ Spatially and temporally resolved degradation in antisolvent treated perovskite films [1 1365-27]

$113650 \mathrm{U}$ Plasmonic metal-oxide core-shell nanoparticles for enhanced power conversion efficiency of organic solar cells [11365-32]

$11365 \mathrm{OW}$ Ultrafast photophysical studies and femtosecond third-order nonlinear optical properties of a Soret-band excited zinc phthalocyanine [11365-35]

$113650 \mathrm{X}$ Photosensitive junctions based on UV-modified graphene and inkjet-printed organic molecules [1 1365-36] 
Proc. of SPIE Vol. 11365 1136501-4 Downloaded From: https://www.spiedigitallibrary.org/conference-proceedings-of-spie on 26 Apr 2023
Terms of Use: https://www.spiedigitallibrary.org/terms-of-use 


\section{Authors}

Numbers in the index correspond to the last two digits of the seven-digit citation identifier (CID) article numbering system used in Proceedings of SPIE. The first five digits reflect the volume number. Base 36 numbering is employed for the last two digits and indicates the order of articles within the volume. Numbers start with 00, 01, 02, 03, 04, 05, 06, 07, 08, 09, 0A, 0B...0Z, followed by 10-1Z, 20-2Z, etc.

Biswas, Chinmoy, ow

Bobrinetskiy, Ivan, OX

Brabec, Christoph J., 05

Choi, Hoyeon, $0 Q$

Das, Abhijit, OU

Dhawan, Anuj, ou

Emelianov, Aleksei, OX

Fischer, Leon-Daniel, 00

Flavell, Wendy, $0 Q$

Frenzel, Tobias, 00

Giribabu, Lingamallu, OW

Göötz, Britta, 05

Hübner, Tobias, 05

Jonnadula, Venkata Suman Krishna, OW

Katturi, Naga Krishnakanth, OW

Ke, Chun-Ren, $0 Q$

Kireev, Dmitry, OX

Kumar, Kamal, OU

Kumawat, Uttam K., OU

Nekrasov, Nikita, OX

Omerović, Nejra, OX

Parkinson, Patrick, $O Q$

Raavi, Sai Santosh Kumar, OW

Skalsky, Stefan, $0 Q$

Soma, Venugopal Rao, OW

von Malm, Norwin, 05 
Proc. of SPIE Vol. $113651136501-6$

Downloaded From: https://www.spiedigitallibrary.org/conference-proceedings-of-spie on 26 Apr 2023
Terms of Use: https://www.spiedigitallibrary.org/terms-of-use 


\title{
Conference Committee
}

\author{
Symposium Chairs
}

Francis Berghmans, Vrije University Brussel (Belgium)

Thierry Georges, Oxxius SA (France)

Paul C. Montgomery, University of Strasbourg (France)

Lluis Torner, ICFO Barcelona (Spain)

Conference Chairs

Sebastian Reineke, TU Dresden (Germany)

Koen Vandewal, TU Dresden (Germany)

Wouter Maes, University Hasselt (Belgium)

Conference Programme Committee

Artem A. Bakulin, Imperial College London (United Kingdom)

David Beljonne, Université de Mons (Belgium)

Vladimir Dyakonov, Julius-Maximilians- Universität Würzburg (Germany)

Malte C. Gather, University of St. Andrews (United Kingdom)

Peter Ho, National University of Singapore (Singapore)

Kristiaan Neyts, University Gent (Belgium)

Markus Clark Scharber, Johannes Kepler Universität Linz (Austria)

Franky So, North Carolina State University (United States)

Natalie Stingelin, Georgia Institute of Technology (United States)

He Yan, Hong Kong University of Science and Technology

(Hong Kong, China)

Eli Zysman-Colman, University of St. Andrews (United Kingdom)

\section{Session Chairs}

1 Organic Electronic Devices and OLEDs I

Sebastian Reineke, TU Dresden (Germany)

2 OLED Materials

Wouter Maes, University Hasselt (Belgium)

3 Organic Electronic Devices and OLEDs II

Sebastian Reineke, TU Dresden (Germany)

4 Spectroscopy and Fundamentals I

Koen Vandewal, University Hasselt (Belgium) 
5 Organic Photodetectors

Wouter Maes, University Hasselt (Belgium)

6 Spectroscopy and Fundamentals II

Sebastian Reineke, TU Dresden (Germany) 